\title{
Systematic review and meta-analysis of bovine cysticercosis in Brazil: current knowledge and way forward
}

\author{
Gabriel Augusto Marques Rossi ${ }^{1 *} \mathbb{B}$, Inge Van Damme ${ }^{2}$ and Sarah Gabriël ${ }^{2}$
}

\begin{abstract}
Background: Taenia saginata taeniosis/cysticercosis has been well studied in several countries. Brazil is one of the most important beef exporting countries and has one of the highest cattle population size in the world. In this country, bovine cysticercosis (BCC) remains the most frequent reported zoonosis detected during post-mortem inspection, resulting in costs for the beef sector and public health. We performed a systematic literature review regarding data about BCC epidemiology in Brazil and meta-analyses for its prevalence in different administrative regions and the distribution over time, and based on this discussed possible control strategies.

Methods: A systematic review was conducted to obtain data about BCC in Brazil using the words "bovine cysticercosis" and "Brazil" to construct the search phrase. The inclusion criteria used to select articles were: (i) published from 2000 to 2018; (ii) full text available online in Portuguese or English; and (iii) contain information at least regarding one of the following aspects of BCC in Brazil: prevalence, incidence, spatial distribution, risk-factors, economic burden and measures for control.

Results: A set of 42 articles was included, covering the prevalence of BCC in Brazil, ranging between 0.01-18.75\%. Prevalence results of 40 articles were included in a meta-analysis per administrative region. The highest prevalence was found in the South (3.4\%; $95 \% \mathrm{Cl}: 2.0-5.2 \%)$, followed by the Southeast (2.7\%; 95\% Cl: 1.9-3.6\%), Northeast (1.5\%; 95\% Cl: 0.6-2.7\%), Central-western (0.9\%; 95\% Cl: 0.3-1.7\%) and North (0.0\%; 95\% Cl: 0.0-0.6\%) region. In addition, a reduction in prevalence over time was observed in all the evaluated states except for Alagoas and Pará.

Conclusions: Besides the large availability of data, a critical lack of information about BCC epidemiology remains in Brazil. Nevertheless, the available data on prevalence, high risk-areas and risk factors should contribute to a better understanding of transmission and the formulation of recommendations for control. A One Health approach will be required to reduce T. saginata taeniosis/cysticercosis prevalence and the consequent economic burden for the beef sector in Brazil, one of the most important beef exporters in the world.
\end{abstract}

Keywords: Beef inspection, Brazil, Bovine cysticercosis, Cattle, Spatial distribution, Taenia saginata

\section{Background}

Bovine cysticercosis (BCC) is an infection caused by the metacestode larval stage of Taenia saginata after the

\footnotetext{
*Correspondence: gabrielrossiveterinario@hotmail.com

${ }^{1}$ Centro Universitário Central Paulista (UNICEP), Rua Miguel Petroni 5111, Postal Code 13563-470 São Carlos, São Paulo, Brazil

Full list of author information is available at the end of the article
}

accidental ingestion of eggs, mainly through consumption of contaminated feed or water. The environmental contamination originates from the definitive hosts (humans) which harbor the adult tapeworms in their intestines (taeniosis) that release proglottids and eggs daily into the environment, either via migrating proglottids or proglottis/eggs in the stool. Taeniosis occurs 
through consumption of raw or undercooked beef containing viable cysticerci [1], after which an adult tapeworm develops in the intestine, generally without clinical symptoms.

BCC and T. saginata taeniosis are widespread in several developing and industrialized countries in Europe [2], Africa [3], the Americas [4], Russian Federation [5] and Asia [6]. For control and prevention of human infections, post-mortem examinations are performed in cattle slaughterhouses. The latter result in economic burden due to inspection costs, carcass condemnation, costs related to carcass treatment according to national regulations (freezing, drying or canning), the non-export of beef and penalties imposed on farmers supplying cattle infected with cysticercosis $[7,8]$.

Beef production and export is an important economic activity in Brazil. The cattle population size is estimated at 214.9 million of animals and the country exported 1.64 million of tons of beef in 2018; the highest amount ever exported among all exporting countries $[9,10]$. BCC remains endemic in Brazil, with frequent detection during meat inspection resulting in a high economic burden for the beef sector [11]. Considering the very low sensitivity of meat inspection [12], a significant number of viable cysticerci will still reach the consumer through infected beef. From a public health perspective, a relatively high number of taeniosis cases has been described $[13,14]$, which confirms the food safety issue and requires urgent control [7].

In the last two decades, several researchers have performed studies focused on an improved understanding of the epidemiology and spatial distribution of BCC in order to obtain useful data for the development and adoption of strategies for control. The data obtained in Brazil should contribute to an improved knowledge about BCC prevalence, areas considered with higher risk, risk factors and other variables associated with its occurrence in this country, and the economic burden. Thus, our aims were: (i) to compile and analyze data regarding BCC epidemiology, spatial distribution and economic burden in Brazil; (ii) to perform meta-analyses of BCC prevalence, for different administrative regions and to evaluate the distribution over time; and (iii) based on the obtained data to discuss useful strategies for control.

\section{Methods}

\section{Study area}

Brazil is the largest country in South America (area of 8 million $\mathrm{km}^{2}$ ) and has over 208 million inhabitants distributed over 5570 municipalities. The Federative Republic of Brazil is composed of the union of 27 federative units: 26 states and 1 Federal District (DF) (located in Goiás State) (Fig. 1).

\section{Search strategy}

We followed the PRISMA guidelines for systematic reviews [15] (Additional file 1: Table S1). A review of literature published from 2000 to 2018 was conducted to obtain data about the prevalence, geographical distribution, risk factors and other variables associated with $\mathrm{BCC}$, its economic burden and recommendations for BCC control in international bibliographic databases included in Google Scholar (https://scholar.googl e.com.br/). As our focus was strictly on BCC and not taeniosis, the keywords ("Bovine cysticercosis" AND "Brazil") OR ("Cisticercose bovina" AND "Brasil") (Portuguese), were used to construct the search phrase in this database. The specific time interval was constructed as 2000 (initial) and 2018 (final).

Subsequently, the compilation was performed, the duplicate records were removed and the relevance of the results was analyzed. The following inclusion criteria were used to select articles: (i) studies performed in Brazil; (ii) published in peer review journals from 2010 to 2018; (iii) full text available online in Portuguese or English; and (iv) contain information at least regarding one of these aspects of $\mathrm{BCC}$ in Brazil: prevalence, incidence, spatial distribution, risk-factors, economic burden and measures for control (Fig. 2). The articles considered as not eligible were those published before 2000 or after 2018 and/or with no access to full text and/or not performed in Brazil and/or out of scope.

\section{Data analysis}

Quantitative data were stored in a predefined spread sheet document, including the study area (state), period of the study, authors and year of publication, number of animals, number of infected animals, prevalence, method of detection and economic burden (when available). Additionally, data were recorded per state, so for studies that reported $\mathrm{BCC}$ data in different states, different rows (one for each state) were created. Another spreadsheet was used to store data about risk-factors studies. Qualitative data on high-risk areas or related to $\mathrm{BCC}$ control were extracted and compiled in other tables.

All analyses were carried out using $\mathrm{R}$ version 3.5.2 [16]. A meta-analysis was performed on the occurrence of BCC in Brazil according to Wang [17] using the meta package (version 4.9-6) [18]. The double arcsine transformation was applied for proportions (number of cases/ total number of animals) prior to analysis. A subgroup analysis was performed to calculate a prevalence estimate per administrative region, assuming a common betweenstudy variance. For studies reporting results for multiple states, data of different states within the same region 
were combined by summing the number of positive cases and the total number of animals.

To evaluate the effect of time on the occurrence of $\mathrm{BCC}$ in Brazil, results were recorded per state/year combination. For state/year combinations that were reported by multiple studies, the numbers of different studies were combined by adding the number of positive cases and the total number of animals tested. A logistic a Brazilian regions

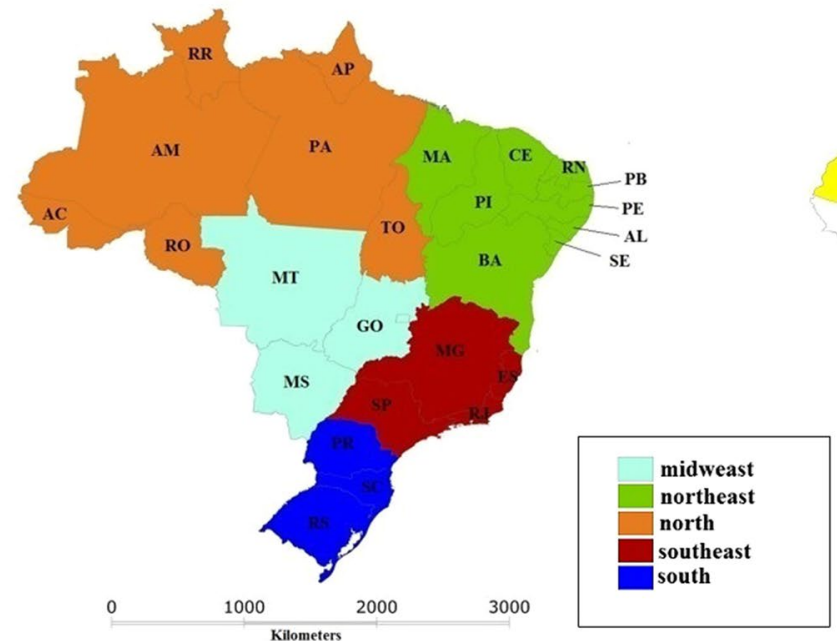

b Human population size



c Human population density

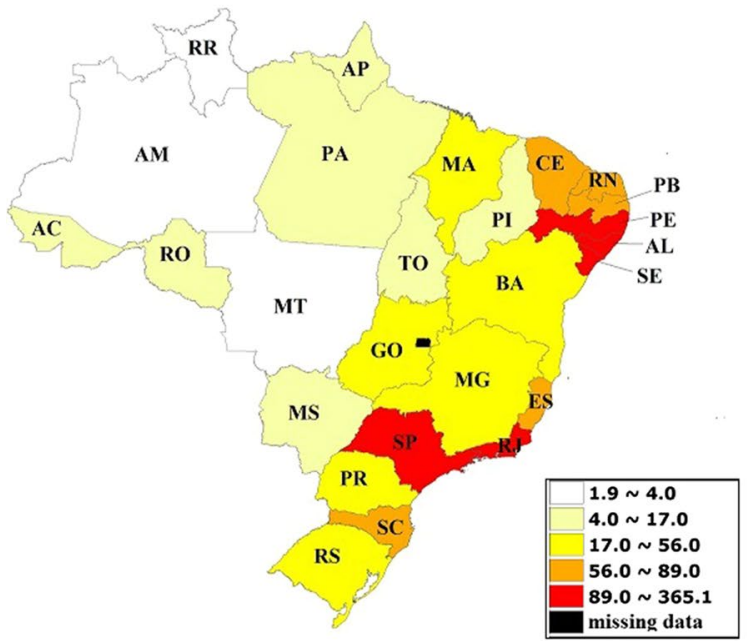

d Cattle population size

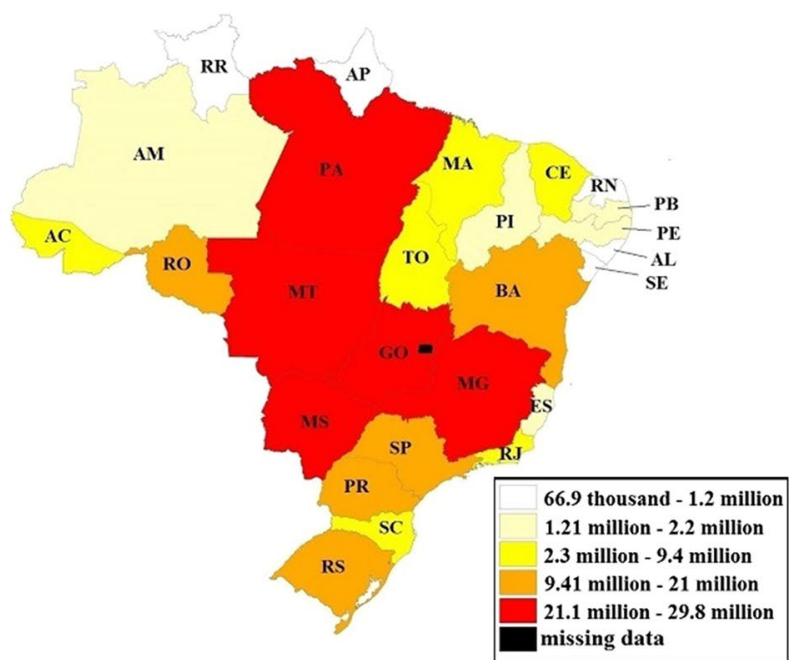

Fig. 1 Maps showing administrative regions, human and cattle populational characteristics according to the The Brazilian Institute of Geography and Statistics (IBGE) (https://www.ibge.gov.br/). a Brazil is divided into the following states: Acre (AC), Alagoas (AL), Amapá (AP), Amazonas (AM), Bahia (BA), Cerá (CE), Espírito Santo (ES), Goiás (GO), Maranhão (MA), Mato Grosso (MT), Mato Grosso do Sul (MS), Minas Gerais (MG), Pará (PA), Paraíba (PB), Paraná (PR), Pernambuco (PE), Piauí (PI), Rio de Janeiro (RJ), Rio Grande do Norte (RN), Rio Grande do Sul (RS), Rondônia (RO), Roraima (RR), Santa Catarina (SC), São Paulo (SP), Sergipe (SE) and Tocantins (TO), which are divided into five Brazilian regions (Midwest, Northeast, North, Southeast and South). b Human population size estimated for 2018 in 26 states. c Human population density estimated for 2018 in 26 states. d Cattle population size in 2017. The maps were created in Terraview ${ }^{\circledR}$ Software (INPE, São José dos Campos, Brazil, v.4.2.2) (http://www.dpi.inpe.br/ terraview) 
regression was used to evaluate the effect of time on the occurrence of BCC, using the year (as a continuous variable) and state (as a factor variable) as main effects and including the two-way interaction between year and state to allow for a different time effect in each state. To evaluate if the interaction term was significant, a likelihood ratio (LR) chi-square test was used.

\section{Results}

A set of 42 peer-reviewed published articles containing prevalence values (Additional file 2: Table S2) [7, 11, 19-58] and one describing the incidence of BCC in areas in Brazil was found in literature [59]. From these articles, we identified two articles $[11,26]$ describing BCC prevalence in several Brazilian states, covering a long period and including a large sample size. In addition, we found 12 articles containing information about the spatial distribution of BCC inside/within the states (Table 1), 13 articles describing risk factors or variables associated with BCC occurrence (Table 2) and 4 describing the economic burden of BCC [7, 22, 28, 30]. Furthermore, a set of 10 studies performed in Brazil were also included, regarding at least one aspect presented in discussion section, such as efficacy of chemical treatment $(n=1)$ [62], preferential infection sites $(n=2)[63,64]$, development of serological tests $(n=4)[65-68]$ and measures for BCC control $(n=3)$ [69-71].

\section{Incidence, prevalence and spatial distribution in Brazil}

There was only one study performed in Brazil which describes the incidence of BCC from 2013 to 2016 in five Brazilian municipalities located in the state of Rio Grande do Sul (RS): Arroio Grande (0.72\%), Canguçu (0.58\%), Capão do Leão (1.31\%), Pelotas (1.06\%) and São Lourenço (0.83\%) [59]. Furthermore, a set of 42 articles was found containing prevalence values and other additional information such as the period, method, state, administrative region, number of examined animals and number of cases (Additional file 2: Table S2).

Post-mortem inspection (meat inspection) was the most used method (34 articles) to detect infected animals, with only eight studies using serological tests (ELISA as trial and immunoblot confirmatory). The $\mathrm{BCC}$ prevalence described in these 42 studies ranged from $0.01 \%$ in the state of Rondônia [34] to $18.75 \%$ in indigenous villages in the state of Mato Grosso do Sul [35].

Forty studies were included in the meta-analysis of BCC in the different Brazilian regions (Fig. 3). One study was excluded because the total number of animals was not provided [28] and another study was excluded as animals from three states (SP, MG and GO) were used without specifying the number of animals per state [34]. Most studies were conducted in the Southeast region $(n=21)$, whereas only three studies examined BCC in the North region. The highest prevalence was found in the South region (3.4\%; 95\% CI: $2.0-5.2 \%)$, followed by the Southeast (2.7\%; 95\% CI: $1.9-3.6 \%)$, Northeast (1.5\%; 95\% CI: 0.6-2.7\%), Central-western (0.9\%; 95\% CI: $0.3-1.7 \%)$ and North regions (0.0\%; 95\% CI 0.0-0.6\%) (Fig. 3).

Only two studies using post-mortem inspection [11, 26] included animals from several Brazilian states and sampled a high number of animals $(75,983,590$ and 146,346,244 animals, respectively) covering a long period (more than three years). Dutra et al. [26] included animals from Acre, Alagoas, Amazonas, Bahia, Espírito Santo, Goiás, Mato Grosso, Mato Grosso do Sul, Minas Gerais, Pará, Paraná, Rio de Janeiro, Rio Grande do Sul, Rondônia, Santa Catarina, São Paulo, Sergipe and Tocantins from 2007 to April 2010, while Rossi et al. [11] studied the period from 2010 to 2015 using animals from the same states except for Alagoas. These studies were used to evaluate the occurrence of BCC over time.

The prevalence of $\mathrm{BCC}$ significantly decreased over time ( $\operatorname{LR} \chi^{2}=125044, d f=1, P<0.001$ ), although the time effect differed between the different states (LR $\left.X^{2}=9029, d f=17, P<0.001\right)$. A reduction in BCC prevalence was observed for all included states, except for Pará and Alagoas. The observed and predicted time distribution of BCC in the five states with most data (Goiás, Mato Grosso, Mato Grosso do Sul, Minas Gerais and São Paulo) is illustrated in Fig. 4. The states that had the highest prevalence of bovine cysticercosis were Rio Grande do Sul, Santa Catarina, São Paulo and Paraná. The observed prevalence within these states varied between $2.8-3.7 \%$ in 2007 [26]. Although the prevalence in these five states decreased to $1.3-1.5 \%$ in 2015 [11], they remained the highest among the different states. In Pará, Alagoas, Amazonas and Tocantins, the prevalence remained below $0.5 \%$ throughout the entire study period (2007-2015).

In addition, the spatial distribution within nine Brazilian states also has been studied (Table 1). These data summarize the areas considered with a higher risk or prevalence of $\mathrm{BCC}$ within nine states using data from 12 studies.

\section{Risk factors}

There were several variables considered as risk factors for BCC in Brazil, which are presented in the 13 studies included in Table 2. Briefly, these factors were linked to areas with large human population, temporary workers involved in crop production, cattle access to uncontrolled water sources, animal purchasing, failures in sanitary education, basic sanitation, rainfall index and farm and farmers characteristics. 


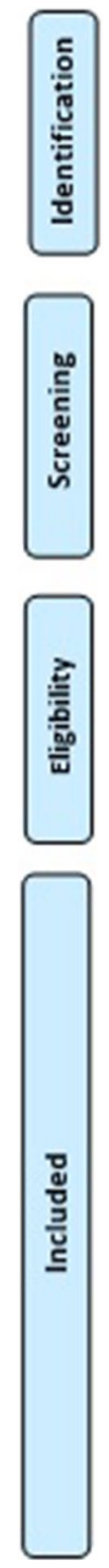

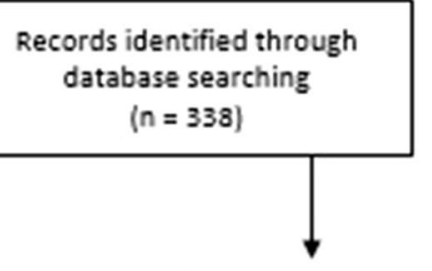

Records after duplicates removed ( $n=197$ )
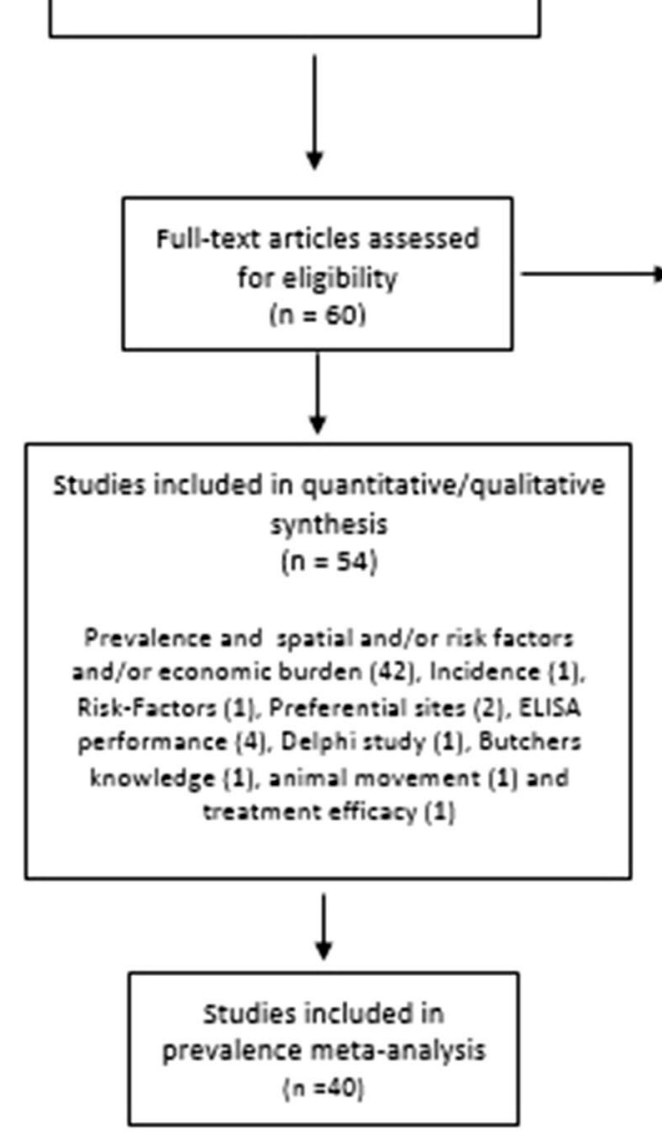

Additional records identified through other sources

( $n=0)$
Full-text articles excluded

$(n=7)$

-Incomplete data

-Wrong theme

Fig. 2 Prisma flowchart diagram of the record selection process

\section{Economic burden}

$\mathrm{BCC}$ leading to reduced carcass value or total carcass condemnation at slaughter, results in important economic losses for the Brazilian beef sector. Four articles presented data about the economic burden [7, 22, 29, 30].

A total of $29,708,550 \mathrm{~kg}$ of beef was condemned for cysticercosis during 2004-2008 in Paraná State, resulting in an economic burden of around USD 31,915,700 due to carcass condemnation [29]. The economic burden for farmers was reported for other states as well, such as: (i) in Minas Gerais State, where farmers had economic losses of USD 537,526.80 due to the detection of 4243 infected bovines from 2009 to 2016 [30]; (ii) states of Minas Gerais, São Paulo, Mato Grosso and Mato Grosso do Sul, where a group of farmers delivering animals to a single slaughterhouse lost USD 312,194.52 during one year [7]; and (iii) in Goiás State, where farmers had economic losses ranging from USD 9,260,728.57 to $11,313,816.67$ from 2007 to 2014 [22]. 
Table 1 Bovine cysticercosis high-risk areas within nine Brazilian states

\begin{tabular}{|c|c|c|c|}
\hline State & Method & Areas with higher risk & \\
\hline Bahia & PM inspection & $\begin{array}{l}101 \text { municipalities located at Itapetinga, Litoral Sul, Médio Rio de Contas, } \\
\text { Vitória da Conquista and Extremo Sul territories }\end{array}$ & Bavia et al. [33] \\
\hline Espírito Santo & PM inspection & Counties: Ecoporanga, Linhares, Presidente Kennedy and Itapemirim & Avelar et al. [28] \\
\hline Goiás & PM inspection & $\begin{array}{l}\text { The Central mesoregion was considered as the one with the highest } \\
\text { prevalence and the microregions of Goiânia, Anápolis, Pires do Rio, Vale } \\
\text { do Rio dos Bois, Meia Ponte e Anicuns (OR>5) }\end{array}$ & Aquino et al. [22] \\
\hline \multirow[t]{2}{*}{ São Paulo } & PM inspection & $\begin{array}{l}\text { Highest prevalence in regions Central, Ribeirão Preto and Presidente } \\
\text { Prudente; higher probability of finding infected animals in regions of } \\
\text { Araçatuba, Barretos, Bauru, Franca and Sorocaba }\end{array}$ & Ferreira et al. [39] \\
\hline & PM inspection & $\begin{array}{l}\text { Higher risk in the administrative regions São José do Rio Preto and } \\
\text { Campinas }\end{array}$ & Rossi et al. [25] \\
\hline \multirow[t]{2}{*}{ Paraná } & PM inspection & $\begin{array}{l}\text { Municipalities of Campo Largo, Capanema, Rosário do Ivaí, Japira, Joaquim } \\
\text { Távora, Laranjeiras do Sul, Rio Bonito do Iguaçu, Palmas, Saudades do } \\
\text { Iguaçu and Antônio Olinto }\end{array}$ & Souza et al. [45] \\
\hline & PM inspection & $\begin{array}{l}\text { Higher prevalence in nucleus of Curitiba, Francisco Beltrão and Irati; higher } \\
\text { OR in nucleus of União da Vitória, Francisco Beltrão and Irati }\end{array}$ & Guimarães-Peixoto et al. [29] \\
\hline Mato Grosso & PM inspection & $\begin{array}{l}\text { Highest OR in the administrative regions Sinop, Barra do Garças, Água } \\
\text { Boa, Cáceres, Barra do Bugres, Cuiabá, Pontes Lacerda, Rondonópolis, } \\
\text { Matupa, São Félix do Araguaia and Lucas do Rio Verde }\end{array}$ & Rossi et al. [21] \\
\hline \multirow[t]{2}{*}{ Mato Grosso do Sul } & PM inspection & $\begin{array}{l}\text { Higher risk in the administrative regions Amambai, Navirai, Nova Andra- } \\
\text { dina, Dourados, Três Lagoas, Campo Grande, Ponta Porã, Costa Rica, } \\
\text { Aquidauana and Coxim }\end{array}$ & Pereira et al. [23] \\
\hline & PM inspection & Municipalities of Dourados and Santa Rita do Rio Pardo & Concenço et al. [60] \\
\hline Paraíba & ELISA and immunoblot & $\begin{array}{l}\text { Higher prevalence in animals in Borborema, Agreste/Zona da Mata and } \\
\text { Sertão }\end{array}$ & Maia et al. [27] \\
\hline Rondônia & PM inspection & $\begin{array}{l}\text { Higher risk in the administrative regions Porto Velho, Guajará-Mirim, Colo- } \\
\text { rado D'Oeste, Cacoal, Ji-Paraná }\end{array}$ & Alves et al. [24] \\
\hline
\end{tabular}

\section{Discussion}

\section{Epidemiology}

High human population density has been reported as a risk factor for BCC in Brazil [21, 23]. In some Brazilian states, such as São Paulo, Espírito Santo, Minas Gerais, Paraná, Santa Catarina, Bahia, Paraíba and Rio Grande do Sul, a high prevalence was observed (mostly $>2 \%$ ) (Additional file 2: Table S2). These states are located mainly in the Southeast and South regions, which had the highest $\mathrm{BCC}$ prevalence values in the prevalence meta-analyses and also a higher human population density (86.82 and 48.58 inhabitants $/ \mathrm{km}^{2}$, respectively) [72]. In the UK, farms situated close to a permanent potential source of human fecal contamination are considered with a higher risk for BCC [73] as the presence of infected humans results in environmental contamination with $T$. saginata eggs, mainly in areas with inappropriate sewage systems [24]. The wastewater treatment in Brazil evolved from $42 \%$ of the Brazilian human population in 2007 to $50.3 \%$ in 2015 , leaving more than 100 million of inhabitants without proper sanitation. According to the Brazilian Institute of Geography and Statistics, only $55.16 \%$ of the 5565 Brazilian municipalities had sewerage systems in 2008. There is a difference in the percentage of municipalities containing sewage collector systems among
Brazilian regions. The South region is the one with the highest value $(95.08 \%$ of the municipalities) followed by the Northeast (45.68\%), South (39.73), Central-western $(28.33 \%)$ and North (13.36\%) regions [74]. However, the Southeast is the second region with a high prevalence of $\mathrm{BCC}$, demonstrating that basic sanitation is not enough to avoid animal's infection through the ingestion of $T$. saginata eggs. Open defecation and underuse of sanitary facilities have also been demonstrated to contribute to maintain taeniosis/cysticercosis in endemic areas [75] and these practices could contribute to $\mathrm{BCC}$ transmission in Brazil but data are lacking to assess the magnitude.

In Brazil, beef cattle are raised mostly extensive [76], where cattle feeding occurs in large areas of pastures with free access to uncontrolled water sources. The relation with access to contaminated water has been described by several authors in Brazil, detailing risks such as the free access of cattle to uncontrolled water sources [7], the presence of flooded pastures [27] or areas with a high rainfall index [23], proximity to rivers and their tributaries that fed municipalities [47], and poor quality of water [37]. Similar risk factors have been reported in other countries, such as the access to risky water sources with sewage treatment effluent plant in proximity [77], the flooding of pastures and free access to surface water, 







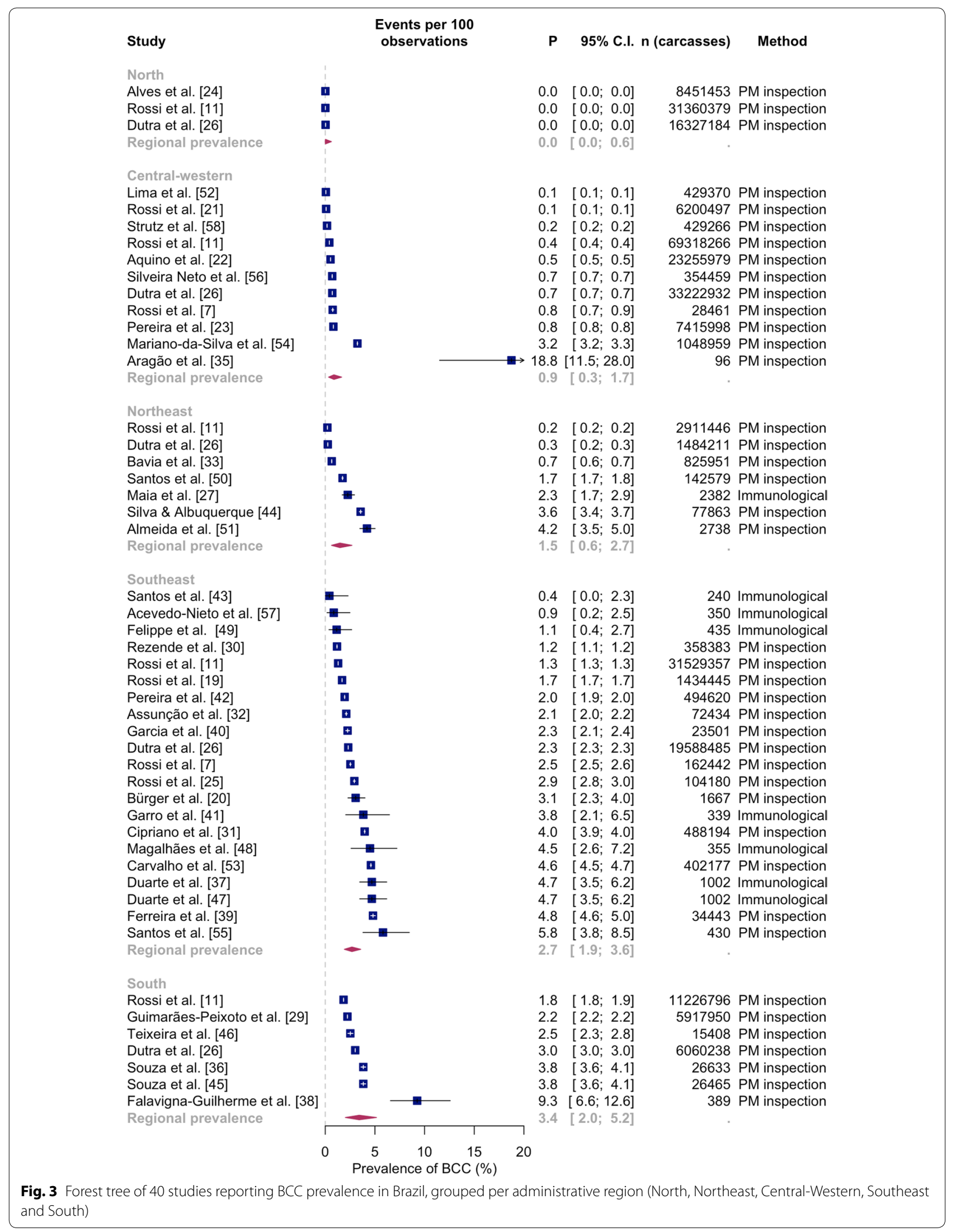




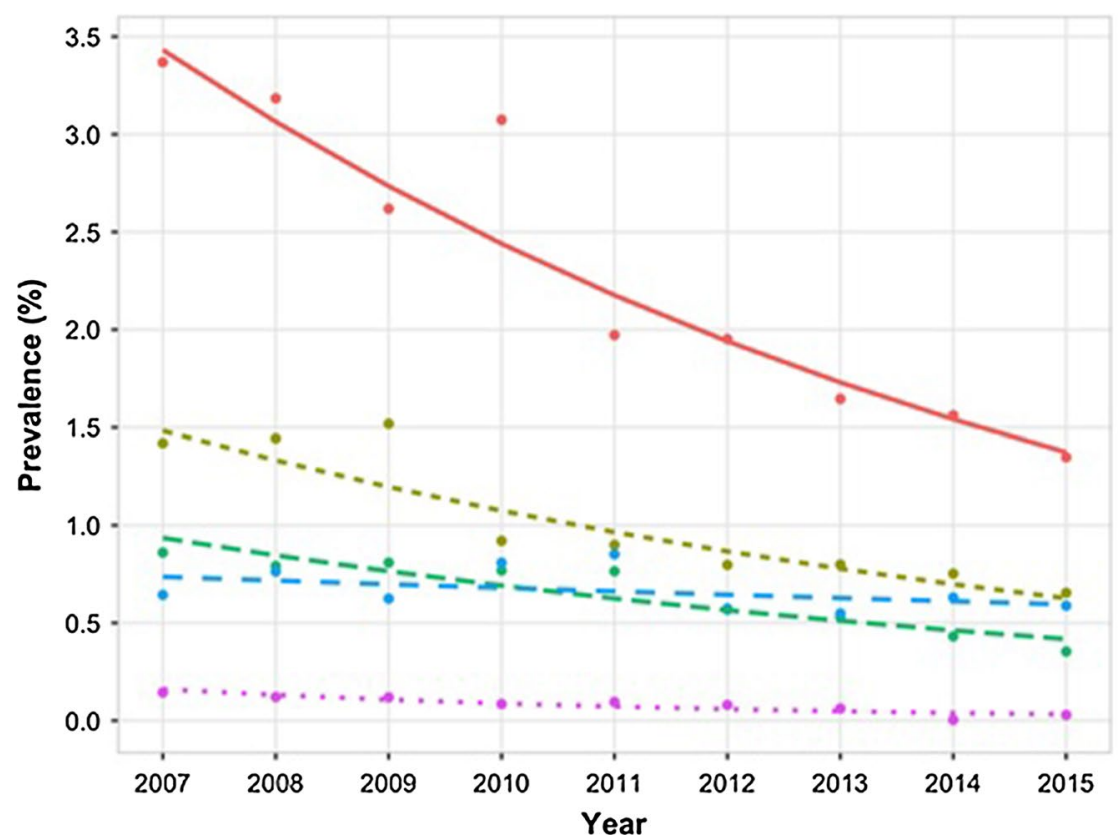

States

$\longrightarrow$ saOpaulo

- - - MATOGROSSO DO SUL

$-\div-$ GOLAS

- - minas gerals

... MATO grosso

Fig. 4 Time distribution of BCC prevalence in five Brazilian states where most data regarding BCC were available (Goiás, Mato Grosso, Mato Grosso do Sul, Minas Gerais and São Paulo) from 2007 to 2015. The points represent the observed data and the lines are the predicted probabilities. Data are from Dutra et al. [26] and Rossi et al. [11]

and the proximity of wastewater effluent [78]. Water supply for animals appears to be the most frequent route of infection for animals in Spain [79].

Raising animals near areas where sugarcane, coffee and orange are harvested has been identified as a risk factor for BCC in Brazil, which is probably due to the presence of temporary workers [25, 39]. Similarly, hiring contractors has been considered as a risk factor for BCC in Denmark $[77,80]$. In Brazil, the adoption of new technologies in crop production, leading to a decrease in human labor needs, could, in combination with the increase of proper sewage treatment systems, explain the $\mathrm{BCC}$ reduction over the time (Fig. 4).

Other important factors related to $\mathrm{BCC}$ have been shown in other countries and may be applicable to Brazil. Allowing animals outdoor access (grazing) is a risk factor reported from Denmark [77, 80] and a common practice in Brazil, where animals have free access to large pastures [76]. Brazil has a large dairy production chain producing 33.8 billion liters of raw milk during 2018 [81], whereby the old dairy cows, may be at a higher risk as reported in Denmark [80] and Spain [79]. Large farms with high numbers of animals are other reported risk factors [78, 79] that may apply to the Brazilian conditions.

\section{Economic burden}

Globally, only few countries have made in depth calculations on the economic impact of $T$. saginata. In northeastern Spain, where the prevalence is low $(0.010 \%$ from 2008-205), the overall impact of $T$. saginata amounted to $€ 154,903 /$ year during 2013 to 2015 and meat inspection accounted for $81.9 \%$ of the costs, followed by carcass condemnation and freezing $(9.4 \%)$ and taeniosis (8.7\%) [82]. In Belgium, the highest proportion of the total economic losses is borne by cattle farmers (economic cost of $€ 3,408,455 /$ year), mainly due to insurance fees. Cost related to taeniosis amount to $€ 795,858 /$ year [8]. Both studies highlight the lack of available data that would allow more accurate assessments. The same is true for Brazil, for which only four articles were found that evaluated the economic burden of $\mathrm{BCC}$ based on condemnation in slaughterhouses, varying between USD 312,194.52 (for a group of farmers at the states of Minas Gerais, São Paulo, Mato Grosso and Mato Grosso do Sul, which supplied a single slaughterhouse during 2012) and USD 31,915,700 (in Paraná between 2004 and 2008). Beef production is an important industry in Brazil, with a Livestock Gross Domestic Product (GDP) in 2018 around USD 144 billion, being responsible for $8.7 \%$ of the Brazilian GDP [83]. While the reported articles provide important information, results are fragmented and do not allow establishment of the real economic impact, requiring further studies for a better comprehension. 


\section{How to control Taenia saginata in Brazil?}

For the control of parasitic zoonosis, such as taeniosis, a "One Health" approach including human, animal and environmental health have been suggested [84, 85]. To achieve sustained control, a multidisciplinary approach should be implemented (Fig. 5), joined with a monitoring and surveillance programme.

The most commonly applied control strategy is the detection of infected carcasses at slaughter via visual meat inspection [86]. The post-mortem examination of carcasses aims to avoid infected animals entering into the food supply chain. However, meat inspection is notorious for its low sensitivity, mainly in carcasses with light infections [87-89] which are common in Brazil [7]. According to some studies, the sensitivity of meat inspection ranged from $0.54 \%$ [12] up to $2.87 \%$ in an enhanced meat inspection system [90] in other countries. The post-mortem inspection for $\mathrm{BCC}$ is performed through visual inspection and multiple incisions in muscles (masseters, pterygoids, tongue and heart). If cisticerci are detected, the lesions are identified and the half carcasses, together with the viscera and the head, are sent to the Final Inspection Department (DIF), where they are examined by a veterinarian $[91,92]$ through complementary visual examination, palpation and incisions in the head, liver, esophagus, diaphragm and the carcass's external surfaces. According to Brazilian literature, the detection occurs mainly during exams of head muscles, liver, tongue and heart [45], but the parasite can be found in other sites such as chuck, rump, strip loin, full tenderloin, back ribs and shoulder [63, 64]. The Brazilian Regulation of Industrial and Sanitary Inspection of Animal Products (RIISPOA) states that animals with heavy infections must be condemned. According to Brazilian law, heavy infections are characterized using the following criteria: at least eight cysticerci (viable or not viable) distributed as follows: (i) two or more cysticerci simultaneously in two preferential sites (masseter and pterygoid muscles, tongue, heart, diaphragm, liver and esophagus), totalizing four cysticerci; and (ii) four or more cysticerci on the chuck, brisket and shank, or on loins and round [92]. Carcasses with a single viable cysticercus must have it removed and be heattreated using $-10{ }^{\circ} \mathrm{C}$ during at least ten days or through salt use during 21 days, while carcasses containing only one not viable cysticercus must have it removed, also, the carcass is considered unsuitable for export. Finally, moderate infections (more than one cysticercus, but lower than the heavy infections) require canning or cooking at a temperature of $76.6^{\circ} \mathrm{C}$ for at least $30 \mathrm{~min}$ [92]. No studies have been performed assessing the sensitivity of the Brazilian meat inspection system.

Some authors have been suggesting to perform meat inspection on animals categorized according to their risk of harboring cysticerci, because it is thought more efficient and sensitive than traditional methods [93, 94]. This risk-based system could be assessed for Brazil, as there are several risk factors and associated variables described for BCC in this country (Table 2). The use of serological analyses, such as Ag-ELISA, to detect infected animals also has been suggested but might not be feasible during slaughter [12]. However, serological analyses have been largely carried out, including in Brazil [65-68] and its use to detect infected animals has improved worldwide [90, $95,96]$, allowing to perform well-designed epidemiological studies.

Considering the low sensitivity of meat inspection and problems related to the detection of infected carcasses using other methods, other strategies for BCC control are required in Brazil, in order to interrupt taeniosis/ cysticercosis transmission. According to a Delphy study performed by experts in $\mathrm{BCC}$ epidemiology, there are six categories of control measures: (i) health education; (ii) health intersectorality; (iii) health surveillance and legislation; (iv) sanitation measures; (v) epidemiological studies; and (vi) methods of diagnosis and treatment [70].

Johansen et al. [97] highlighted that "ignorance is the major obstacle for the effective control of diseases"; indeed, educating the population about amongst others sanitation and the consumption of well-cooked beef is an important strategy to interrupt $T$. saginata taeniosis/ cysticercosis transmission [70]. Children are recognized as excellent health change agents $[98,99]$, highlighting the need to include them in educational programmes. A study including middle and high school students in Brazil showed that approximately $75 \%$ of interviewed students had never heard the words "cysticercosis" or "taeniosis" [20]. Besides education of the general population, targeted information for specific groups such as farmers, butchers, should be addressed as well, as the ignorance about cysticercosis/taeniosis was also shown in butchers in Brazil [69]. Electronic educational tools have been successfully used for T. solium control in endemic countries $[97,100,101]$ and the adoption of a similar tool for T. saginata could be useful in Brazil. Specific flyers and information notes have been developed in the framework of CYSTINET, the European Network for taeniosis/cysticercosis (COST Action TD1302) (http://www.cystinet.org), which may also be adapted to the Brazilian situation.

To date, beef inspection services only communicate with the animal's owner when cysticercosis is detected during slaughter. Unfortunately, this is not followed by an investigation or activity conducted by animal health agencies. The detection of cysticercosis during post-mortem exams should be communicated to health departments, including origin and farm location, 


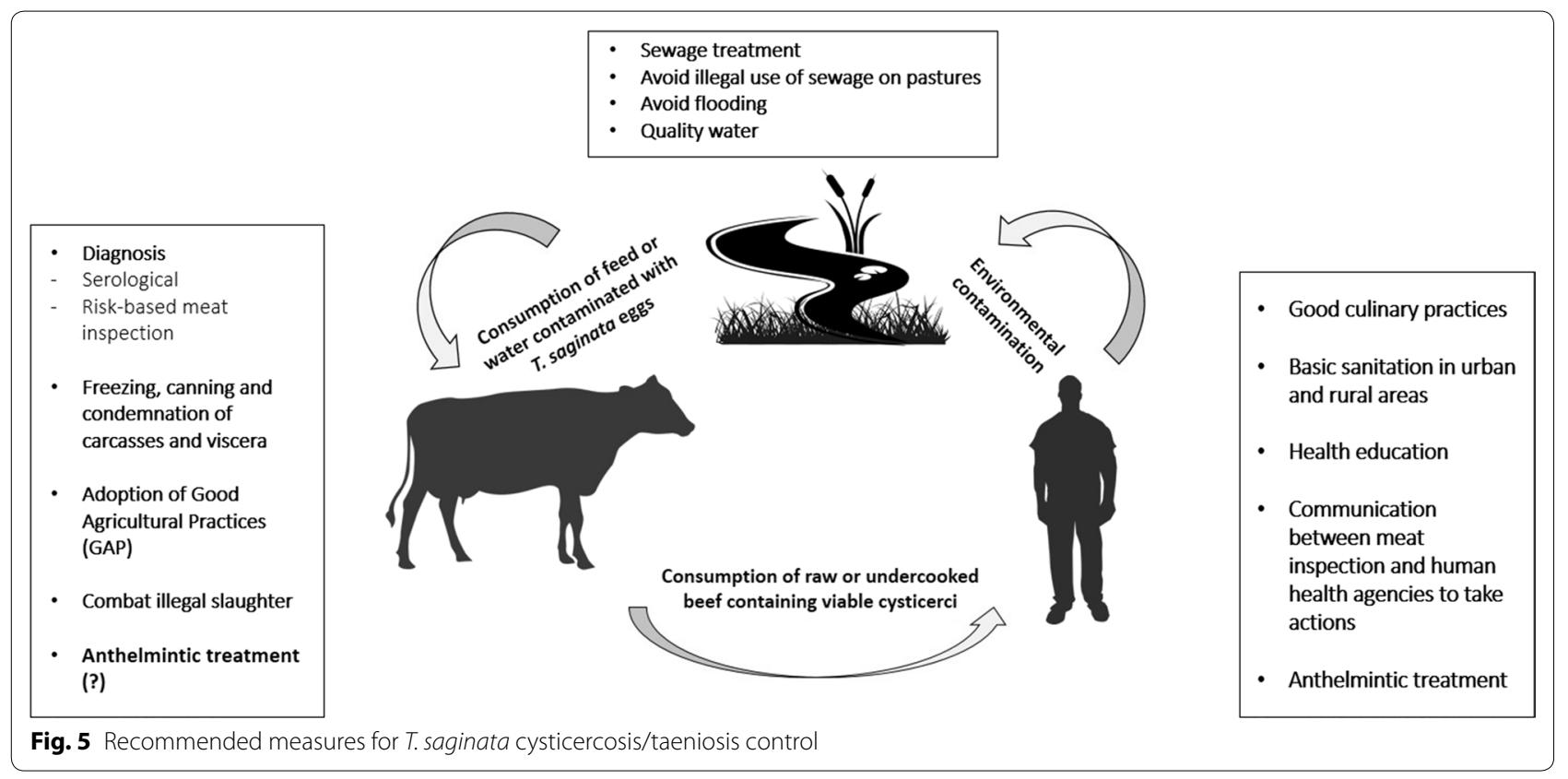

so that actions, i.e. including health education programmes and human treatment, may be taken on the different levels including integrated activities among professionals of the program for family health, educators and workers [70].

The identification of the locations where the animals become infected is often complicated in Brazil, due to the movement of animals between farms in the course of their lives. Animal's movement can complicate the interpretation of results obtained from epidemiological studies [102]. The use of animal movement network analysis to map farms serving as contamination sources have been studied in Brazil with interesting results. The detection of farms with risk of $T$. saginata infection using this network along with the proper sanitary management and human treatment resulted in a decrease in BCC prevalence, from $25 \%$ in 2010 to $1.8 \%$ in 2012 [71].

Another control measure that needs improvement in Brazil is the combat against illegal slaughter [70], a recognized practice that occurs in Brazil, allowing infected animals to enter in food supply chain. There are no official data for the current situation of illegal slaughter in Brazil.

Anthelmintic treatment of infected cattle has been suggested; however, the currently available and tested anthelmintics (albendazole sulphoxide and albendazole) gave inconsistent efficacy results [62]. Since animal treatment in Brazil has been rather unsuccessful, a better health management for cattle remains key in controlling T. saginata [70]. It means the adoption of practices able to interrupt the transmission of BCC through ingestion of eggs present in contaminated water, pastures and animal food, such as basic sanitation or proper animal management. As previously discussed, there is a risk for grazing in contaminated pastures due overflooding of rivers contaminated with $T$. saginata eggs or drinking contaminated water. The adoption of good agricultural practices (GAP) in beef farms including measures such as to avoid the ingestion of uncontrolled water sources or contaminated food must contribute to its control. The slaughterhouses must encourage and require this quality tool from farms during implementation of hazard analysis and critical control points (HACCP) in order to avoid risk for consumers due consumption of viable cysticerci in beef [7].

\section{Conclusions}

Besides the large amount of data available about the occurrence and risk factors of cysticercosis in Brazil, which contributed to improve the knowledge, a critical lack of information still remains, mainly regarding the economic impact and assessments of strategies for $\mathrm{BCC}$ control. There is an urgent need for interventions through a "One Health" approach in order to continue reducing the $\mathrm{BCC}$ prevalence in Brazil, contributing to improving human health and reducing the economic burden for the beef sector in one of the most important beef-exporting countries in the world.

\section{Supplementary information}

Supplementary information accompanies this paper at https://doi. org/10.1186/s13071-020-3971-0. 


\section{Additional file 1: Table S1. PRISMA checklist.}

Additional file 2: Table S2. The set of 42 studies performed in areas located at Brazil published from 2000 to 2018 presenting the period, method, state, administrative region, number of examined animals, number of cases and prevalence of BCC in Brazil.

\section{Acknowledgements}

Not applicable.

\section{Authors' contributions}

GAMR, IVD and SG designed the work, analysis, interpretation of data, drafted the manuscript and substantively revised it. All authors read and approved the final manuscript.

\section{Funding}

Not applicable.

\section{Availability of data and materials}

The data supporting the conclusions of this study are provided within the article. All datasets generated and analyzed during this study are available from the corresponding author upon reasonable request.

\section{Ethics approval and consent to participate}

Not applicable.

\section{Consent for publication}

Not applicable.

\section{Competing interests}

The authors declare that they have no competing interests.

\section{Author details}

${ }^{1}$ Centro Universitário Central Paulista (UNICEP), Rua Miguel Petroni 5111, Postal Code 13563-470 São Carlos, São Paulo, Brazil. ${ }^{2}$ Department of Veterinary Public Health and Food Safety, Faculty of Veterinary Medicine, Ghent University, Ghent, Belgium.

Received: 12 December 2019 Accepted: 14 February 2020 Published online: 21 February 2020

\section{References}

1. Murrell KD, Dorny P, Flisser A, Geerts S, Kyvsgaard NC, McManus DP, et al. WHO/FAO/OIE guidelines for the surveillance, prevention and control of taeniosis/cysticercosis. Paris: World Organisation for Animal Health (OIE); 2005.

2. Laranjo-González M, Devleesschauwer B, Gabriël S, Dorny P, Allepuz A. Epidemiology, impact and control of bovine cysticercosis in Europe: a systematic review. Parasit Vectors. 2016;9:81.

3. Dermauw V, Dorny P, Braae UC, Devleesschauwer B, Robertson LJ, Saratsis A, et al. Epidemiology of Taenia saginata taeniosis/cysticercosis: a systematic review of the distribution in southern and eastern Africa. Parasit Vectors. 2019;11:578.

4. Braae UC, Thomas LF, Robertson LJ, Dermauw V, Dorny P, Willingham AL, et al. Epidemiology of Taenia saginata taeniosis/cysticercosis: a systematic review of the distribution in the Americas. Parasit Vectors. 2018;11:518.

5. Bobic B, Thomas LF, Djakovic OD, Devleesschauwer B, Dermauw $V$, Dorny $P$, et al. Epidemiology of Taenia saginata taeniosis/cysticercosis in the Russian Federation. Parasit Vectors. 2018;11:636.

6. Torgerson PR, Abdybekova AM, Minbaeva G, Shapiyeva Z, Thomas LF, Dermauw $V$, et al. Epidemiology of Taenia saginata taeniosis/cysticercosis: a systematic review of the distribution in central and western Asia and the Caucasus. Parasit Vectors. 2019;12:175.

7. Rossi GAM, Hoppe EGL, Mathias LA, Martins AMCV, Mussi LA, Prata LF. Bovine cysticercosis in slaughtered cattle as an indicator of good agricultural practices (GAP) and epidemiological risk factors. Prev Vet Med. 2015;118:504-8.

8. Jansen F, Dorny P, Trevisan C, Dermauw V, Laranjo-González M, Allepuz $A$, et al. Economic impact of bovine cysticercosis and taeniosis caused by Taenia saginata in Belgium. Parasit Vectors. 2018;11:241.

9. ABIEC. Brazilian Association of Beef Exporters. Exportações brasileiras de carne bovina fecham 2018 com recorde histórico (in Portuguese). 2019. http://www.abiec.com.br/download/exportacoes\%20fecham\%20com \%20recorde.pdf Accessed 15 Jan 2019.

10. IBGE. The Brazilian Institute of Geographic and Statistics. Ppm 2017: Rebanho bovino predomina no centro-oeste e Mato Grosso lidera entre os estados. 2018. https://agenciadenoticias.ibge.gov.br/agenc ia-sala-de-imprensa/2013-agencia-de-noticias/releases/22648-ppm2017-rebanho-bovino-predomina-no-centro-oeste-e-matogrosso-lider a-entre-os-estados Accessed 15 Jan 2019 (in Portuguese).

11. Rossi GAM, Martins IVF, Campos RF, Soares LFS, Almeida HMS, Mathias LA. Spatial distribution of bovine cysticercosis-a retrospective study in Brazil from 2010 through 2015. Prev Vet Med. 2017;145:145-9.

12. Jansen F, Dorny P, Berkvens D, Gabriël S. Bovine cysticercosis and taeniosis: the effect of an alternative post-mortem detection method on prevalence and economic impact. Prev Vet Med. 2018;161:1-8.

13. Santos SA, Merlini LS. Prevalence of enteroparasitosis in the population of Maria Helena, Paraná State. Cienc Saude Colet. 2010;15:899-905 (In Portuguese)

14. Jeske S, Biachin TF, Moura MQ, Baccega B, Pinto NB, Berne MEA, et al. Intestinal parasites in cancer patients in the south of Brazil. Braz J Biol. 2018;78:574-8

15. Moher D, Liberati A, Tetzlaff J, Altman DG, Group P. Preferred reporting items for systematic reviews and meta-analyses: the PRISMA statement. PLoS Med. 2009;6:e1000097.

16. R Core Team. R: A language and environment for statistical computing. Vienna, Austria: R Foundation for Statistical Computing; 2017. https:// www.R-project.org/.

17. Wang MAN. Conducting Meta-Analyses of Proportions in R: A comprehensive tutorial. 2018. https://www.researchgate.net/publication/32548 6099_How_to_Conduct_a_Meta-Analysis_of_Proportions_in_R_A_ Comprehensive_Tutorial. Accessed 10 Dez 2019.

18. Schwarzer G. Meta: an R package for meta-analysis. R News. 2007;7:40-5.

19. Rossi GAM, Garnica MF, Almeida HMS, Ribeiro LF, Martins AMC, Bürger KP, et al. Swine and bovine cysticercosis - occurrence in slaughterhouses located at São Paulo State, Brazil. Rev Bras Cienc Vet. 2015;22:202-15 (In Portuguese).

20. Bürger KP, Buzza PLT, Buzza-Neto E, Santos LR, Rossi GAM, Martins AMCV. Taeniosis-cysticercosis: occurrence during cattle slaughter and students and consumer knowledge in the central region of São Paulo State, Brazil. Rev Bras Cienc Vet. 2015;22:23-7 (In Portuguese).

21. Rossi GAM, de Simoni HAS, Lopes WDZ, Almeida HMS, Soares VE, Vidal AMC, et al. Prevalence and geospatial distribution of bovine cysticercosis in the state of Mato Grosso, Brazil. Prev Vet Med. 2016;130:94-8.

22. Aquino FM, Soares VE, Rossi GAM, Danin LAC, Nicaretta JE, Bastos TSA, et al. Analysis of bovine cysticercosis in the state of Goiás, Brazil and economical losses for beef farms. Parasitol Open. 2017;3:e12.

23. Pereira MN, Rossi GAM, Lopes WDZ, Almeida HMS, Mathias LA, Soares $V E$, et al. Spatial analysis of bovine cysticercosis in the state of Mato Grosso do Sul, Brazil — the needs of interventions in animal and human populations. Vet Parasitol Reg Stud Reports. 2017;8:94-8.

24. Alves WC, Rossi GAM, Lopes WDZ, Almeida HMS, Mathias LA, Vidal AMC, et al. Geospatial distribution and risk factors for bovine cysticercosis in the state of Rondônia, Brazil. Pesq Vet Bras. 2017;37:931-6.

25. Rossi GAM, Lopes WDZ, Almeida HMS, Soares VE, Aguilar CE, Vidal AMC, et al. Spatial distribution, prevalence and epidemiological risk factors of cysticercosis in cattle from state of São Paulo, Brazil, slaughtered for human consumption. Vet Parasitol Reg Stud Reports. 2014:8:117-22.

26. Dutra LH, Girotto A, Vieira RFC, Vieira TSWJ, Zangirolamo AF, Marquês FAC, et al. The prevalence and spatial epidemiology of cysticercosis in slaughtered cattle from Brazil. Semin Cienc Agrar. 2012;33:1887-96.

27. Maia ARA, Fernandes LG, Pinto PSA, Guimarães-Peixoto RPM, Silva LF, Santos CSAB, et al. Herd-level seroprevalence and associated risk factors for bovine cysticercosis in the state of Paraíba, northeastern Brazil. Prev Vet Med. 2017;142:51-7. 
28. Avelar BR, Marcelino LC, Campos RF, Santos AR, Martins IVF. Spatial analysis on the risk of bovine cysticercosis occurrence in the state of Espírito Santo, Brazil. Parasite Epidemiol Control. 2016;1:116-23.

29. Guimarães-Peixoto RPM, Souza VK, Pinto PSA, Santos TO. Distribution and identification of risk areas for bovine cysticercosis in the state of Paraná, Brazil. Pesq Vet Bras. 2012;32:975-9 (In Portuguese)

30. Rezende MTNP, Komatsu RS, Andrade RB, Reis SLB, Leite CR, Rocha SR, et al. Economic losses due the occurrence of cysticercosis in cattle from cities located in Minas Gerais, Brazil. Cienc Rural. 2018;48:e20180483.

31. Cipriano RC, Faria PB, Guimarães GC, Mascarenhas DR. Bovine cysticercosis prevalence in slaughterhouse with state inspection in Espírito Santo state, Brazil. Rev Bras Cienc Vet. 2015;22:54-7 (In Portuguese).

32. Assunção EF, Ferreira IM, Braga HF. Bovine cysticercosis and tuberculosis prevalence in an exporter slaughterhouse of Campina Verde. MG. PUBVET. 2014;8:1783 (In Portuguese)

33. Bavia ME, Carneiro DDMT, Cardim LL, Silva MMN, Martins MS. Spatial scan statistic in the detection of risk areas for bovine cysticercosis in the state of Bahia. Arq Bras Med Vet Zootec. 2012;64:1200-8 (In Portuguese)

34. Costa RFR, Santos IF, Santana AP, Tortelly R, Nascimento ER, Fukuda RT, et al. Characterization of Cysticercus bovis lesions at postmortem inspection of cattle by gross examination, histopathology and polymerase chain reaction (PCR). PesqVet Bras. 2012;32:477-84.

35. Aragão SC, Biondi GF, Lima LGF, Nunes CM. Animal cysticercosis in indigenous Brazilian villages. Rev Bras Parasitol Vet. 2010;19:132-4.

36. Souza VK, Pessôa-Silva MC, Kowalczuk M, Marty S, Thomaz-Soccol V. Anatomic regions of major occurrence of Cysticercus bovis in bovines under federal inspection at slaughterhouse in the municipality of São José dos Pinhais, State of Paraná from July to December, 2000. Rev Bras Parasitol Vet. 2017;16:92-6 (In Portuguese).

37. Duarte CTD, Pinto PSA, Silva LF, Santos TO, Acevedo-Nieto EC, Almeida LP. Transmission and prevalence profile of bovine cysticercosis in rural properties of Triangulo Mineiro, Brazil. Pesq Vet Bras. 2016;36:793-7 (In Portuguese)

38. Falavigna-Guilherme AL, Silva K, Araújo SM, Tobias ML, Falavigna DLM. Cysticercosis in animals of Sabáudia, Paraná state. Arq Bras Med Vet Zootec. 2006;58:950-1 (In Portuguese).

39. Ferreira MM, Revoredo TB, Regazzi JP, Soares VE, Ferraldo AS, Mendonça RP, et al. Prevalence, spatial distribution and risk factors for cattle cysticercosis in the state of São Paulo, Brazil. Pesq Vet Bras. 2014;34:1181-5 (In Portuguese).

40. Garcia LNN, Pereira MAVC, Miranda FJB, Gomes FF, Resende MA, Lira BR. Cysticercus bovis in bovines under federal inspection (SIF) at slaughterhouse in mountain region of the state of Rio de Janeiro from 2003 and 2004. Rev Bras Parasitol Vet. 2008;17:170-1 (In Portuguese)

41. Garro FL, Santos TM, Assis DCS, Heneine LGD, Ornellas CBD, Pinto PSA, et al. Diagnosis of bovine taeniasis-cysticercosis complex in São João Evangelista, Minas Gerais, Brazil. Arq Bras Med Vet Zootec. 2015;67:1063-9 (In Portuguese).

42. Pereira MAVC, Schwanz VS, Barbosa CG. Prevalence of cisticercosis in slaughtered bovine carcasses in slaughterhouses and cold stores in Rio de Janeiro State Brazil, submitted under the Federal Surveillance Service (SIF-RJ) from 1997 to 2003. Arq Inst Biol. 2006;73:83-7 (In Portuguese)

43. Santos TO, Pinto PSA, lasbik AF, Silva LF, Nieto ECA, Guimarães-Peixoto RPM. Epidemiological survey of taeniasis/cysticercosis complex in cattle farms in Viçosa County, Minas Gerais, Brazil. Pesq Vet Bras. 2013;33:449-52.

44. Silva DR, Albuquerque GR. Cysticercosis in cattle slaughtered under state inspection in the municipality of Vitória da Conquista, BA. Rev Bras Med Vet. 2010;32:225-8 (In Portuguese)

45. Souza VK, Pessôa-Silva MC, Minozzo JC, Thomaz-Soccol V. Bovine cysticercosis prevalence in Parana State, southern of Brazil, in animals slaughtered under the SIF 1710. Semin Cienc Agrar. 2007;28:675-84 (In Portuguese)

46. Teixeira JLR, Recuero ALC, Brod CS. Ambispective cohort study of bovine cysticercosis from slaughterhouses with Municipal Inspection Service (SIM) in the southern Rio Grande do Sul, Brazil. Rev Patol Trop. 2015:44:146-54

47. Duarte CTD, Pinto PSA, Silva LF, Santos TO, Bevilacqua PD, AcevedoNieto EC. Epidemiological aspects of cysticercose in relation to hydrographic net at Triângulo Mineiro, MG, Brazil. Semin Cienc Agrar. 2018;39:221-30.

48. Magalhães FC, Santos TM, Assis DC, Ornellas CD, Pinto PSA, Santos WM. Diagnosis and risk factors of bovine taeniasis-cysticercosis complex in Salinas, Minas Gerais, Brazil. Pesq Vet Bras. 2017;37:205-9 (In Portuguese)

49. Felippe AG, Pinto PSA, Santos TO, Acevedo-Nieto EC, Guimarães-Peixoto RPM, Silva LF. Favorable caracteristic for control of taenisis-cysticercosis complex in a rural region of Minas Gerais, Brazil. Rev Bras Cienc Vet. 2014;21:243-6 (In Portuguese).

50. Santos VCR, Ramos ETR, Almeida-Filho FS, Pinto JMS, Munhoz AD. Prevalence of cysticercosis in cattle slaughtered under federal inspection in the municipality of Jequié, Bahia, Brazil. Cienc Anim Bras. 2008;9:132-9 (In Portuguese)

51. Almeida DO, Igreja HP, Alves FMX, Santos IF, Tortelly R. Bovine cysticercosis in slaughterhouse under sanitary inspection in Teixeira de Freitas-Brazil: prevalence and anatomy pathological analysis of suspected cysticercosis diagnosis. Rev Bras Cienc Vet. 2006;13:178-82 (In Portuguese).

52. Lima RS, França EL, Honorio-França AC, Ferrari CKB. Prevalência de cisticercose bovina e conhecimento sobre a doença em 20 municípios do Mato Grosso. Revista Panoramica Multidisciplinar. 2011;12:46-60. http:// revistas.cua.ufmt.br/revista/index.php/revistapanoramica/article/viewA rticle/19, Accessed 16 Jan 2018

53. Carvalho LT, Costa RFR, Santos IF, Carvalho ALT. Measles prevalence in cattle slaughtered under sanitary inspection in Minas Gerais. Rev Bras Cienc Vet. 2006;13:109-12 (In Portuguese).

54. Mariano-da-Silva S, Rocha RN, Oliveira SL, Costa Netto AP. Prevalência de cisticercose bovina no estado de Goiás. Rev Agrarian. 2012;5:187-92.

55. Santos REV, Santos IF, Bonisson JC. Comparative study between Santos technique for inspection post mortem, and state inspection service for detecting cysticercus bovis at the slaughterhouses in the state of Rio de Janeiro, Brazil. Rev Bras Cienc Vet. 2003;10:175-81 (In Portuguese).

56. Silveira-Neto OJ, Oliveira RR, Pereira FO, Basile ALC, Taveira RZ. Ocorrência e localização de cisticercos em bovinos abatidos e submetidos à inspeção federal no Estado de Goiás, Brasil. PUBVET. 2011;5:1130-5 (In Portuguese)

57. Acevedo-Nieto EC, Ferreira PS, Santos TO, Guimarães-Peixoto RP, Silva LF, Fellipe AG, et al. Prevalence of taeniasis-cysticercosis complex in a rural area of Matias Barbosa-MG. Semin Cienc Agrar. 2012;33:2307-14 (In Portuguese).

58. Strutz D, Penachioni RD, Oliveira JÁ, Santos R, Castro BG. Estudo retrospectivo da ocorrência de cisticercose bovina em matadouro frigorífico de Sinop-MT, Brasil, 2009 a 2014. Rev Patol Trop. 2015;44:295-302 (In Portuguese)

59. Alberti TS, Bruhn FRP, Lansini V, Raffi MB, Scheid HV, Zamboni R, et al. Occurrence of hydatidosis and cysticercosis in cattle in southern Rio Grande do Sul, Brazil, from 2013 to 2016. Pesq Vet Bras. 2018;38:1918-22.

60. Concenço FIGR, Silva CA, Nora L. Occurrence of bovine cysticercosis in animals slaughtered in two facilities at Mato Grosso do Sul state, Brazil. J Consum Prot Food Saf. 2018;3:299-307.

61. Acevedo-Nieto EC, Vieira FC, Pinto PSA, Silva LF, Santos TO, GuimarãesPeixoto RP. Analysis of risk factors for bovine cysticercosis infection: a case control study starting from abated animals. Semin Cienc Agrar. 2012;33:2356-66 (In Portuguese)

62. Lopes WDZ, Cruz BC, Soares VE, Nunes JLN, Teixeira WFP, Maciel WG, et al. Historic of therapeutic efficacy of albendazol sulphoxide administered in different routes, dosages and treatment schemes, against Taenia saginata cysticercus in cattle experimentally infected. Experim Parasitol. 2014;137:14-20.

63. Guimarães-Peixito RPM, Pinto PSA, Silva LF, Acevedo-Nieto EC, Silva AR. Profile of Taenia saginata cysticerci implantation in unusual sites and its importance for public health. Pesq Vet Bras. 2018;38:23-8 (In Portuguese)

64. Lopes WDZ, Santos TR, Soares VE, Nunes JLN, Mendonça RP, Lima RCA, et al. Preferential infection sites of cystiercus bovis in cattle experimentally infected with Taenia saginata eggs. Res Vet Sci. 2011;90:84-8.

65. Guimarães-Peixoto RPM, Pinto PSA, Nero LA, Santos TO, Silva LF, Acevedo-Nieto EC, et al. Performance of the ELISA test for the diagnosis of cysticercosis using experimentally and naturally cattle infected with 
metacestode of Taenia saginata. Semin Cienc Agrar. 2015;36:807-16 (In Portuguese).

66. Silva LF, Pinto PSA, Duarte CTD, Santos TO, Acevedo-Nieto EC, Guimarães-Peixoto RPM. Applicability of ELISA with diferente antigens to diagnosis varying levels bovine cysticercosis. Semin Cienc Agrar. 2015;36:2013-22 (In Portuguese)

67. Guimarães-Peixoto RPM, Pintos PSA, Santos MR, Polêto MD, Silva LF, Silva-Júnior A. Evaluation of a synthetic petptide from the Taenia saginata $18 \mathrm{kDA}$ surface/secreted oncospheral adhesion protein for serological diagnosis of bovine cysticercosis. Acta Trop. 2016;164:463-8.

68. Guimarães-Peixoto RPM, Pinto PSA, Santos MR, Zilch TJ, Apolinário PF, Silva-Júnior A. Development of the multi-epitope chimeric antigen rqTSA-25 from Taenia saginata for serological diagnosis of bovine cysticercosis. PLoS Negl Trop Dis. 2018;12:e0006371.

69. Izola BF, Rossi GAM, Picinato MAC, Hoppe EGL, Martins AMCV, Bürger KP. Meat handlers' knowledge of taeniosis-cysticercosis complex and good manufacturing practices in Jaboticabal, São Paulo state, Brazil. Rev Bras Cienc Vet. 2014;21:123-30 (In Portuguese).

70. Nickele EP, Busato MA. Prevention and control of bovine cysticercosis: a Delphi study. Semin Cienc Agrar. 2016;37:4139-48.

71. Aragão SC, Ito PKRK, Paulan SC, Utsonomyia YT, Grisi-Filho JHH, Nunes CM. Animal movement network analysis as tool to map fams serving as a contamination source in cattle cysticercosis. Pesq Vet Bras. 2017:37:319-24

72. IBGE, Brazilian Institute of Geography and Statistics. Demographic Census 2010. https://censo2010.ibge.gov.br/sinopse/index.php?dados $=10 \& u f=00$. Accessed 18 Nov 2019.

73. Marshall LR, Prakashbabu BC, Ferreira JP, Buzdugan SN, Stark KDC, Guitian J. Risk factors for Taenia saginata cysticercus infection in cattle in the United Kingdom: a farm-level case-control study and assessment of the role of movement history, age and sex. Prev Vet Med. 2016;135:1-8

74. IBGE, Brazilian Institute of Geography and Statistics. Pesquisa Nacional de Saneamento Básico. 2008. https://www.ibge.gov.br/estatistic as-novoportal/multidominio/meio-ambiente/9073-pesquisa-nacionalde-saneamento-basico.html?=\&t=destaques. Accessed 17 Jan 2018 (in Portuguese).

75. Thys S, Mwape KE, Lefèvre P, Dorny P, Marcotty T, Phiri AM, et al. Why latrines are not used: communitie's perceptions and practices regarding latrines in a Taenia solium endemic rural area in eastern Zambia. PLoS Negl Trop Dis. 2015;9:e0003570.

76. Braga GB, Ferreira Neto JS, Ferreira F, Amaku M, Dias RA. Characterization of cattle breeding systems with reproductive in south-central Brazil. Braz J Vet Res Anim Sci. 2015;52:217-27 (In Portuguese)

77. Calvo-Artavia FF, Nielsen LR, Dahl J, Clausen DM, Gaumann AM, Alban L. A case-control study of risk factors for bovine cysticercosis in Danish cattle herds. Zoonoses Public Health. 2012;60:311-8.

78. Boone I, Thys E, Macotty T, Borchgrave J, Ducheyne E, Dorny P. Distribution and risk factors of bovine cysticercosis in Belgin dairy and mixed herds. Prev Vet Med. 2007;82:1-11.

79. Allepuz A, Napp S, Picado A, Alba A, Panades J, Domingo M, et al. Descriptive and spatial epidemiology of bovine cysticercosis in northeastern Spain (Catalonia). Vet Parasitol. 2009;159:43-8.

80. Calvo-Artavia FF, Nielsen LR, Dahl J, Clausen DM, Alban L. Occurrence and factors associated with bovine cysticercosis recorded in cattle at meat inspection in Denmark in 2004-2011. Prev Vet Med. 2013;110:177-82.

81. IBGE, Brazilian Institute of Geography and Statistics. IBGE News. 2018. https://agenciadenoticias.ibge.gov.br/agencia-sala-de-imprensa/2013agencia-de-noticias/releases/25482-ppm-2018-rebanho-bovino-dimin ui-e-produtividade-nacional-de-leite-ultrapassa-2-mil-litros-por-anima I-ao-ano. Accessed 12 Oct 2019.

82. Laranjo-González M, Devleesschauwer B, Jansen F, Dorny P, Dupuy C, Requena-Méndez A, et al. Epidemiology and economic impact of bovine cysticercosis and taeniosis caused by Taenia saginata in northeastern Spain (Catalonia). Parasit Vectors. 2018;11:376.

83. ABIEC. Brazilian Beef Exporters Association. Beef Report. 2019. http:// www.abiec.com.br/controle/uploads/arquivos/sumario2019portugues .pdf. Accessed 13 Jan 2020 (in Portuguese).

84. Torgerson PR. One world heatlh: socioeconomic burden and parasitic disease control priorities. Vet Parasitol. 2013;195:223-32.
85. Gabriël S, Mwape KE, Phiri IK, Devlesschauwer B, Dorny P. Taenia solium control in Zambia: the potholed road to success. Parasite Epidemiol Control. 2018:4:e00082.

86. Okello AL, Thomas LF. Human taeniasis: current insights into prevention and management strategies in endemic countries. Risk Manag Healthc Policy. 2017;10:107-16.

87. Dorny P, Vercammen F, Brandt J, Vansteenkiste W, Berkvens D, Geerts S. Sero-epidemiological study of Taenia saginata cysticercosis in Belgian cattle. Vet Parasitol. 2000;88:43-9.

88. Allepuz A, Gabriel S, Dorny P, Napp S, Jansen F, Vilar MJ, et al. Comparision of bovine cysticercosis prevalence detected by antigen ELISA and visual inspection in the north east of Spain. Res Vet Sci. 2012;92:393-5.

89. Cueto González SA, Rodríguez Castillo JL, López Valencia G, Bermúdez Hurtado RM, Hernández Robles ES, Monge Navarro FJ. Prevalence of Taenia saginata larvae (Cysticercus bovis) in feedlot cattle slaughtered in a federal inspection type abattoir in northwest Mexico. Foodborne Pathog Dis. 2015;12:462-5.

90. Jansen F, Dorny P, Gabriël S, Eichenberger RM, Berkvens A. Estimating prevalence and diagnostic test characteristics of bovine cysticercosis in Belgium in the absence of a 'gold standard'reference test using a Bayesian approach. Vet Parasitol. 2018;254:142-6.

91. Brazil. Ministry of food, agriculture and supply chain. Manual de instruções - Inspeção de carnes - Padronização de técnicas, instalações e equipamentos de bovinos. 1971. http://www.agricultura.gov.br/assun tos/inspecao/produtos-animal/empresario/copy_of_TOMODEBOVI NO.pdf. Accessed 19 Jan 2019 (in Portuguese).

92. Brazil. Ministry of Agriculture, Food and Supply Chain. 2017 March. 29. Decreto 9.013 - Regulation of industrial and sanitary inspection of animal products. Official Gazette, Brasilia, DF, Brazil (in Portuguese)

93. Calvo-Artavia FF, Nielsen LR, Alban L. Epidemiologic and economic evaluation of risk-based meat inspection for bovine cysticercosis in Danish cattle. Prev Vet Med. 2013;108:253-61.

94. Prakashbabu BC, Marshall LR, Crotta M, Gilbert W, Johnson JC, Alban $L$, et al. Risk-based inspection as a cost-effective strategy to reduce human exposure to cysticerci of Taenia saginata in low prevalence settings. Parasit Vectors. 2018;11:257.

95. Jansen F, Dorny P, Berkvens D, Hul AV, Broeck NV, Makay C, et al. High prevalence of bovine cysticercosis found during evaluation of different post-mortem detection techniques in Belgian slaughterhouses. Vet Parasitol. 2017;244:1-6.

96. Eichenberger RM, Lewis F, Gabriël S, Dorny P, Torgerson PR, Deplazes P. Multi-test analysis and model-based estimation of the prevalenceof Taenia saginata cysticercus infection in naturally infected dairy cows in the absence of a'gold standard'reference test. Int J Parasitol. 2013:43:853-9.

97. Johansen MV, Trevisan C, Braae UC, Magnussen P, Ertel RL, Mejer H, et al. The vicious worm: a computer-based Taenia solium education tool. Trends Parasitol. 2014;30:372-4.

98. Mwanga JR, Jensen BB, Magnussen P, Aagaard-Hansen J. School children as health change agents in Magu, Tanzania: a feasibility study. Health Promot Int. 2008:23:16-23.

99. Onyango-Ouma W, Aagaard-Hansen J, Jensen BB. Changing concepts of health and illness among children of primary school age in western Kenya. Health Educ Res. 2004;19:326-39.

100. Ertel RL, Braae UC, Ngowi HA, Johansen MV. Assessment of a computerbased Taenia solium health education tool 'the vicious worm' on knowledge uptake among professionals and their attitudes towards the program. Acta Trop. 2017;165:240-5.

101. Hobbs EC, Trevisan C, Johansen MV, Dorny P, Gabriël P. Value of electronic educational media in combatting parasitic diseases. Trends Parasitol. 2019;35:173-6.

102. Dupuy C, Morlot C, Demont P, Callait-Cardinal MP, Ducrot C, Calavas D, et al. Spatial analysis of bovine cysticercosis in France in 2010. Food Control. 2015:47:348-52.

\section{Publisher's Note}

Springer Nature remains neutral with regard to jurisdictional claims in published maps and institutional affiliations. 